\title{
ARTE Y PROPAGANDA EN ITALIA ANTE LA MUERTE DE CARlos II DE ESPAÑA. IMÁGENES, LIBROS Y PANFLETOS ENTRE Austrias y Borbones
}

\author{
Pablo GonzÁlez Tornel
}

Universitat Jaume I

Resumen: La muerte de Carlos II de Habsburgo, rey de España, en 1700 y sin descendencia directa, desencadenará la guerra de Sucesión a la Corona española entre Francia y el Imperio. Ambas potencias, además de emplear las armas, intentarán legitimar las pretensiones de sus dos candidatos, Felipe, duque de Anjou, y Carlos, archiduque de Austria. Para ello resultará fundamental la propaganda escrita e icónica de la que se analizan algunos ejemplos producidos en Italia y, especialmente, en Roma.

Palabras clave:: guerra de Sucesión, propaganda, Italia, grabado, Barroco.

Abstract: In 1700 the death of Charles II Hapsburg, king of Spain, without direct descent started the Succession War to the Spanish Crown between France and the Empire. Both candidates, Philip, Duke of Anjou, and Charles, Archduke of Austria, tried to legitimize their pretensions and written propaganda, engravings and paintings were used on this purpose. Some pieces of this propaganda produced in Italy, and specially in Rome, are analyzed in this study.

Keywords: Succession War, propaganda, Italy, engraving, Baroque. 
T a muerte de Carlos II de Habsburgo sin descendencia el 1 de noviembre Le 1700 produjo una crisis en Europa que enfrentó a las principales potencias del continente en una guerra que, a pesar de las numerosas paces firmadas, marcaría el devenir político durante casi cuarenta años. La falta de un heredero obligó a Carlos II a testar a favor de uno de los pretendientes al trono español y la elección recayó en el duque de Anjou, Felipe de Borbón. ${ }^{1}$ La designación de un sucesor, conocida tras la apertura de las últimas voluntades del rey, fue solo un hito más en una lucha de poder que, desde hacía años, se había convertido en el principal objetivo de la diplomacia europea. Luis XIV de Francia y Leopoldo I de Habsburgo hacía tiempo que habían dejado claras sus ambiciones sobre los territorios de la monarquía española y el testamento de Carlos II no iba a ser un obstáculo para intentar materializarlas.

La cuestión sucesoria se había convertido para la cúpula del gobierno español en un problema acuciante conforme avanzaba la edad del enfermizo Carlos y la muerte, en 1699, de Fernando de Baviera, designado en dos ocasiones como sucesor, había restringido los candidatos a las estirpes francesa y austriaca. Los Borbones franceses se proclamaban herederos de Felipe IV por el matrimonio de Luis XIII y Luis XIV con dos infantas españolas, hermana e hija del monarca. Por su parte, la dinastía imperial austriaca, además de los derechos adquiridos por matrimonio, esgrimía la pertenencia a un tronco común que descendía del mismísimo padre del emperador Carlos V.

Tanto Francia como Austria cuidaron en la elección de sus candidatos de no provocar el recelo de otras naciones europeas y por ello propusieron a hijos segundogénitos no destinados, en principio, a heredar las respectivas coronas. Los pretendientes fueron Felipe, duque de Anjou, y Carlos, archiduque de Austria, y en medio de este juego político, destinado a convertir a una de las dos familias en la más poderosa de Europa, durante los años previos a la muerte de Carlos II y en los inmediatamente posteriores, la diplomacia jugó un papel fundamental. ${ }^{2}$

El juego de poder es delicado y ambas potencias intentan ganar aliados para su causa tanto preparándose para el conflicto armado como intentando decantar los apoyos para conseguir el reconocimiento pacífico de su candidato, siendo el del Papado el apoyo más buscado. ${ }^{3}$ Sin embargo, junto a la acción de la diplomacia y la presión política, cobra fuerza, especialmente en el medio italiano y concretamente romano, la impresión de panfletos, folletos y libros que explican las razones que sustentan la causa de cada uno de los pretendientes. Se consolidan a través de este medio literario, en ocasiones complementado

1. Domínguez Ortiz, A, Testamento de Carlos II, Editorial Nacional, Madrid,1982.

2. Véase para un análisis pormenorizado del tablero de ajedrez diplomático en que se convirtió Italia Ochoa Brun, Miguel Ángel, Embajadas rivales. La presencia diplomática de España en Italia durante la Guerra de Sucesión, Real Academia de la Historia, Madrid, 2002.

3. Martín Marcos, David, «Roma ante el cambio dinástico en la Monarquía Española. La consulta de Carlos II a Inocencia XII sobre la Sucesión», Hispania, LXVII, 225, 2007, pp. 255-270. 
con imágenes, dos verdaderas campañas propagandísticas muy extensas a las que este estudio procurará aproximarse. ${ }^{4}$

Las razones esgrimidas por cada uno de los bandos tienen una impostación sutilmente distinta e irán marcándose de forma clara conforme avance el conflicto. Tanto Luis XIV como Leopoldo I emplean el parentesco familiar como principal argumento para defender la sucesión al trono español, pero las situaciones de Borbones y Habsburgo con respecto a la línea sucesoria a la corona del Rey Católico son notablemente diferentes. El parentesco directo resulta más cercano en la genealogía francesa y, además, este bando cuenta con la baza ineludible de ser el designado por Carlos II como sucesor. Sin embargo, Leopoldo, conocedor del temor que inspira en el resto de las potencias europeas el expansionismo francés, y consciente de su situación de desventaja en la línea sucesoria, tenderá a apuntalar los derechos de su hijo el archiduque Carlos sobre motivaciones más subjetivas.

Antes de la guerra: Austria reclama su herencia y Francia se TAMBALEA

Muchos años antes de la muerte de Carlos II Leopoldo parece preparar sus pretensiones dinásticas sobre España y aparecen publicados en Italia libros verdaderamente lujosos que cargan las tintas en el ensalzamiento de la dinastía imperial para mayor gloria del emperador. Así ocurre en uno de los de mayor empaque, el Aquila Romana, ${ }^{5}$ verdadera genealogía de la dignidad imperial en la que se recorre, desde Carlomagno, la sucesión de los emperadores de Occidente. El texto va acompañado de grabados a página completa en la que se representan los emperadores formando parte de complejas composiciones alegóricas relativas a sus virtudes. En la página 149, correspondiente al emperador Carlos V, curiosamente, el dibujante ha optado por plasmar un retrato doble de los emperadores y hermanos Carlos V y Fernando I. Ambos, ataviados como césares romanos, aparecen sustentando la figura femenina de la Religión, con el cáliz en la mano y la cabeza cubierta con un velo. La Religión pisa la retorcida alegoría de la herejía mientras el conjunto es sobrevolado por la personificación de la fama que, con una trompeta en la mano izquierda,

4. Para el medio español véanse Pérez Picazo, María Teresa, La publicística española en la Guerra de Sucesión, Consejo Superior de Investigaciones Científicas, Madrid, 1966, y Borreguero BeLtráN, CRistina, «Imagen y propaganda de guerra en el conflicto sucesorio (1700-1713)», Manuscrits, 21, 2003, pp. 95-132. Resultan también interesantes los estudios de GILARD, CELINE, «Héroes y guapos: la Guerra de Sucesión española en los pliegos de cordel», Revista de literaturas populares, V, 2, 2005, pp. 310-331, y Guillamón Álvarez, F.J. Et AliI, La Guerra de Sucesión en los pliegos de cordel, Real Academia Alfonso X el Sabio, Murcia, 2005, aunque, sin duda, la obra de referencia en este campo es GonzÁlez Cruz, DAVID, Propaganda e información en tiempos de guerra. España y América (1700-1714), Sílex, Madrid, 2009.

5. Palazzi, Giovanni, Aquila Romana overo Monarchia Occidentale da Carlo Magno d'Occidente Imperador Primo sino alla Coronatione del Glorioso Leopoldo I, Venecia, por el autor, 1679. (Biblioteca Romana e Emeroteca del Archivio Storico Capitolino). 
sopla por otra de la que sale la cartela con el plus ultra. El reclamo a España resulta evidente, tanto por el lema del plus ultra, como por la presentación del césar Carlos sustentando la maza de Hércules, mítico fundador de la monarquía hispana.

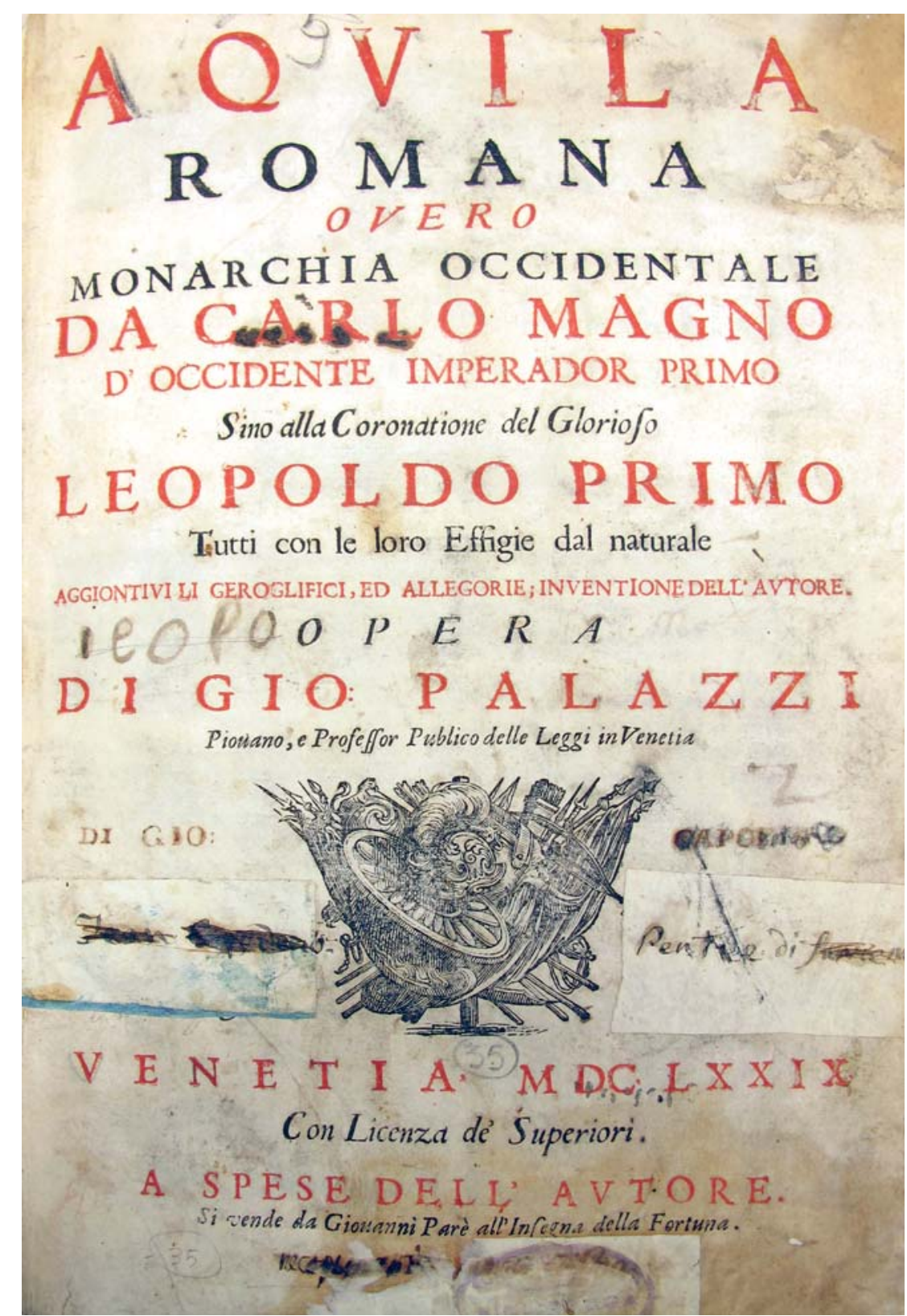

Fig. 1. Palazzi, Giovanni, Aquila Romana overo Monarchia Occidentale da Carlo Magno d'Occidente Imperador Primo sino alla Coronatione del Glorioso Leopoldo I. Biblioteca Romana e Emeroteca del Archivio Storico Capitolino (Roma) 
La compleja imagen alegórica, de una enorme belleza formal, plantea dos conceptos de gran calado: la unidad indisoluble de Carlos y Fernando, que aparecen en el grabado con el mismo semblante, como si fueran idénticos, y el papel de la dinastía Habsburgo como máximo y único protector de la religión católica. Uno y otro concepto se demostrarán fundamentales, unos años después, para apuntalar las pretensiones del archiduque Carlos a la Corona española.

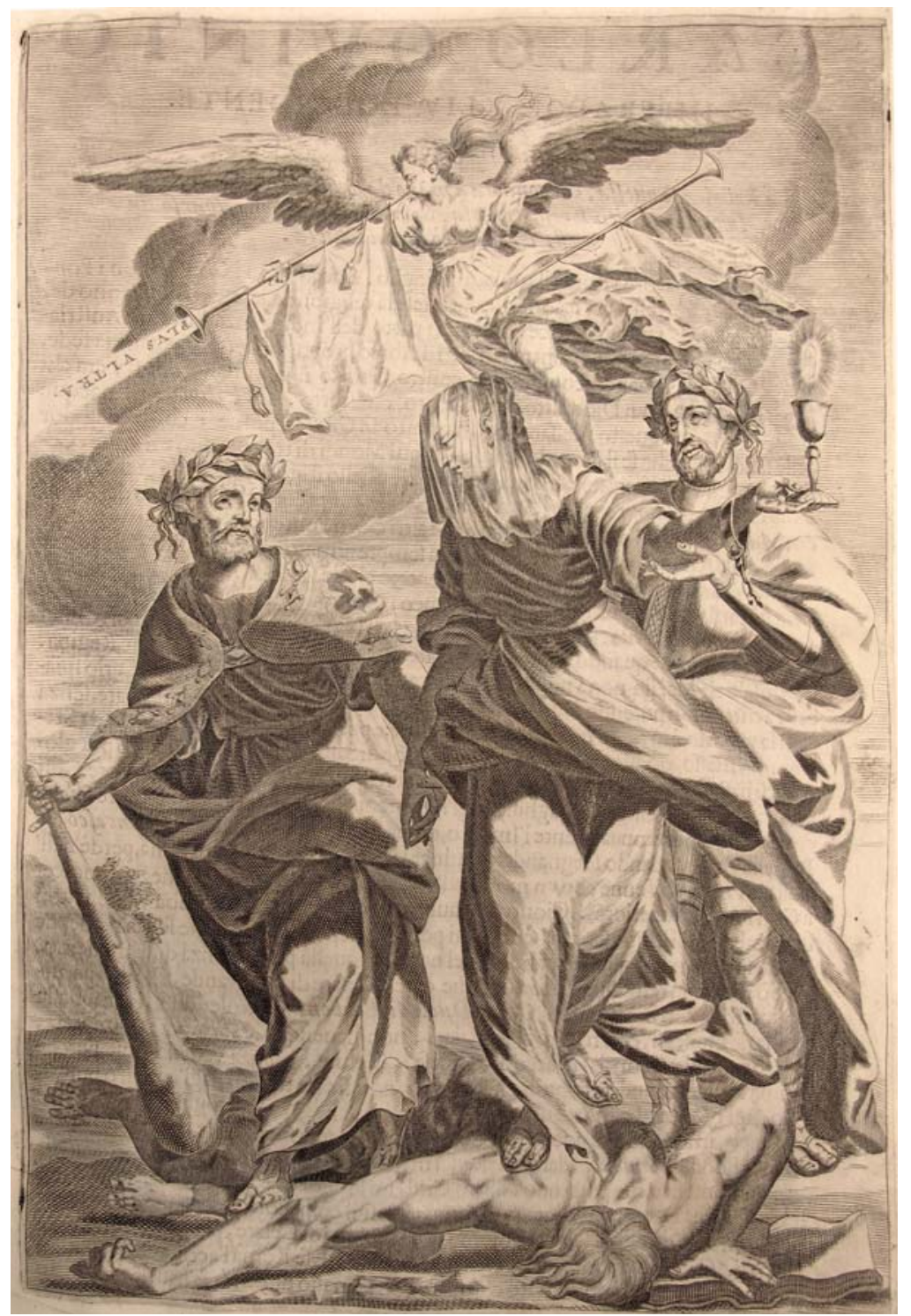

Fig. 2. Grabado alegórico de Carlos V y Fernando I. Palazzi, Giovanni, Aquila Romana overo Monarchia Occidentale da Carlo Magno d'Occidente Imperador Primo sino alla Coronatione del Glorioso Leopoldo I. Biblioteca Romana e Emeroteca del Archivio Storico Capitolino (Roma) 
La inclusión del emperador Carlos V, I de España, dentro de la genealogía imperial de los Habsburgo austriacos tiende a enlazar esta rama de la familia con la española reforzando la unión dinástica. Sin embargo, se trata de una unión ficticia sin una línea de descendencia clara, ya que Carlos y Fernando, hermanos, son, cada uno y por separado, las cabezas de dos ramas diferentes de los Habsburgo. La división de ambas ramas carece de un tronco común que implique derechos sucesorios de los miembros de la rama austriaca sobre la española o viceversa, pues el padre de Carlos y Fernando, Felipe el Hermoso, ni había sido emperador ni rey de Castilla por derecho, sino por matrimonio con Juana la Loca.

En los años finales del siglo, al tiempo que en Roma las embajadas de Austria y Francia recrudecían su actividad para favorecer a sus pretendientes, el bando austriaco ve aumentar sus temores ante el fortalecimiento de la causa francesa y el ataque al rival galo se concreta en publicaciones como la que en 1697 aparece con el nombre de Gallia titubans. ${ }^{6}$ En este texto se advierte a las naciones europeas del peligro que supone el expansionismo francés, se enumeran los males infligidos por Francia y, al mismo tiempo, se avisa a Luis XIV de su delicada situación en el complejo equilibrio europeo. El panfleto está precedido por una significativa imagen femenina que, subida en un pedestal como una diosa romana, se tambalea ante los vientos que parecen querer derribarla. La personificación de Francia aparece claramente identificada tanto por el escrito del pedestal, como por los collares de las órdenes militares del Espíritu Santo y San Miguel, no dejando la estrella de ocho puntas sustentada por una cadena de flores de lis, símbolo de la primera, ninguna duda sobre la identidad de la figura a punto de caer. El paisaje sobre el que se recorta la Francia tambaleante no resulta inocente y aparece plagado de escenas de guerra que muestran las batallas, incendios, violencia y destrucción con que se identifica el expansionismo francés y que serán, según el autor del texto, las que acabarán por provocar la caída del rey galo.

Sin embargo, el detonante de una política propagandística mucho más agresiva por parte del partido austriaco lo constituye una acción que es considerada como una verdadera ofensa por Leopoldo I, la firma del Tratado de División por parte de Francia con la mayoría de los estados europeos. Por este pacto, firmado en vida de Carlos II, se repartían las posesiones de la corona española entre Austria y Francia, tratado que el emperador se negó a firmar defendiendo la indisolubilidad de la herencia de Carlos II.

En este sentido, y también antes del fallecimiento del último Habsburgo español, se publica Lo spartimento del favoloso leone, ${ }^{7}$ aparecido en el mercado italiano aunque, falsamente, el texto afirma haber sido publicado en Colonia.

6. Gallia titubans \& mente titubante resurgens sive Succincta demonstratio, quàm màle hactenus Gallia per actiones suas, summae suae existimationi serviverit: in quantum in tanto existimationis suae periculo, iterum resurgere possit, Grenoble, 1697. (Biblioteca Casanatense).

7. Lo spartimento del favoloso leone verificato dal Re di Francia nella divisione della monarchia di Spagna, Colonia, 1700. (Biblioteca Casanatense). 


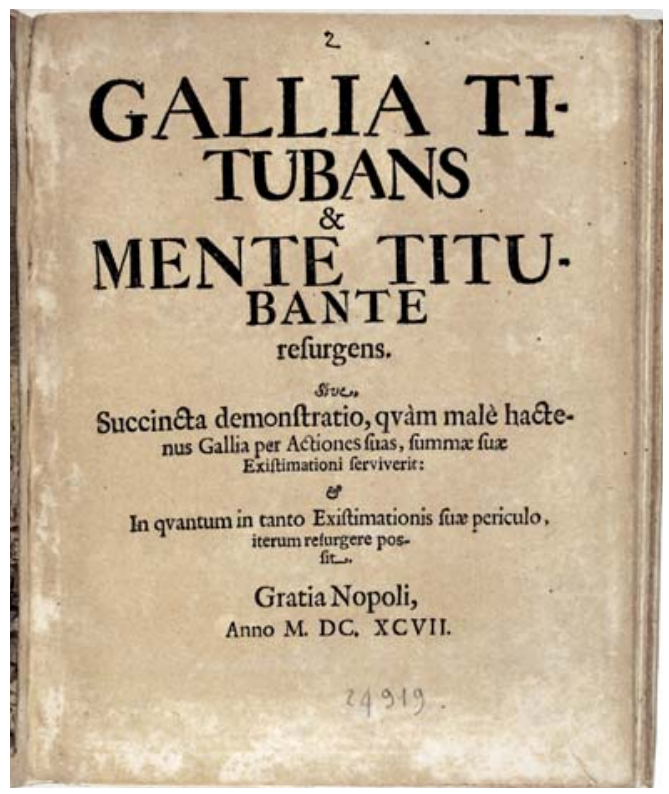

Fig. 3. Portada de Gallia titubans \& mente titubante resurgens sive Succincta demonstratio, quàm màle hactenus Gallia per actiones suas, summae suae existimationi serviverit: in quantum in tanto existimationis suae periculo, iterum resurgere possit. Biblioteca Casanatense (Roma)

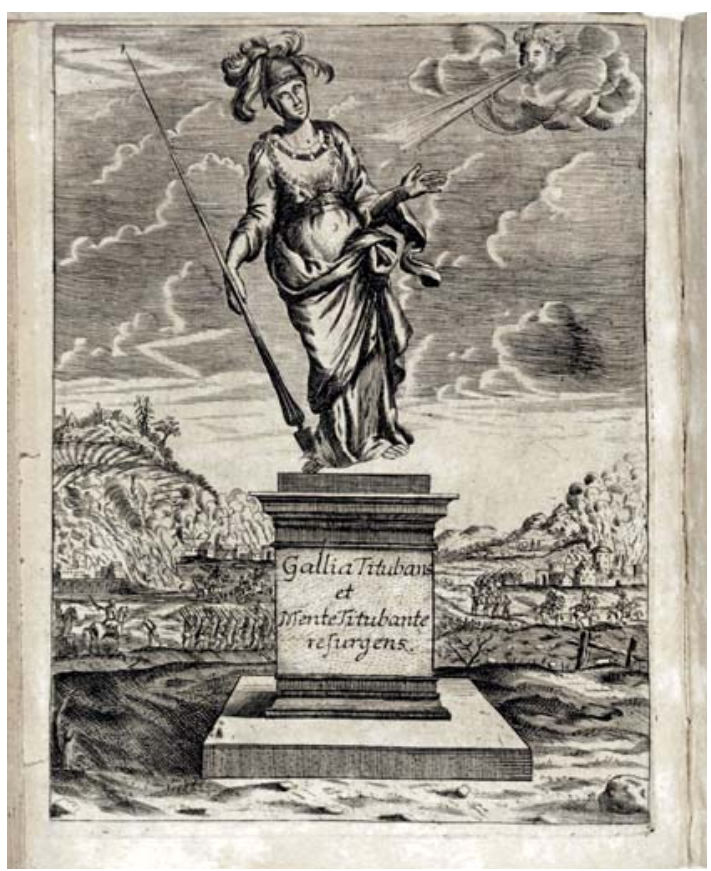

Fig. 4. Frontispicio de Gallia titubans E mente titubante resurgens sive Succincta demonstratio, quàm màle hactenus Gallia per actiones suas, summae suae existimationi serviverit: in quantum in tanto existimationis suae periculo, iterum resurgere possit. Biblioteca Casanatense (Roma) 
La narración comienza con las maquinaciones de Francia en el Tratado de Ryjswick donde, mediante concesiones mesuradas, consigue atraer a su esfera de influencia a Holanda y Saboya y atar la sucesión a la Corona española en la persona del príncipe de Baviera. Se buscaba, de esta manera, hurtar la sucesión a la rama austriaca de los Habsburgo y, al mismo tiempo, reducir los apoyos al emperador Leopoldo. Sin embargo, la muerte del príncipe elector de Baviera obligó a Luis XIV a buscar una nueva estrategia, estableciendo entonces un tratado que sancionaba la división de los territorios de la monarquía hispana. Este Tratado de la División se ha publicado y es considerado una verdadera afrenta contra la casa Habsburgo y, aún más, contra Carlos II que todavía está vivo y con capacidad de engendrar un heredero.

En el libro se realiza un recorrido sobre la progresión de las ambiciones francesas constatable en las paces de los Pirineos, Nimega y Ryjswick, en las que se ha situado, con engaños, al mismo nivel de parentesco que el emperador con respecto a la monarquía española. Sin embargo, como se convertirá en habitual, se reclaman las renuncias a la sucesión de las dos infantas de España casadas con Luis XIII y Luis XIV, que declararían nula cualquier aspiración de los Borbones franceses. Por el Tratado de la División Francia se adueñaría de Nápoles, Sicilia, las fortalezas toscanas, Guipúzcoa, el Marquesado de Finale y la Lorena, a cambio de la cual entregaba Milán al duque titular. $\mathrm{Al}$ archiduque Carlos de Austria le hubieran correspondido los territorios de la península Ibérica, Flandes y las posesiones ultramarinas. El tratamiento injusto, según el texto proaustriaco, deriva del mismo momento en que los territorios adjudicados a Francia pasan directamente a la corona, mientras que los señalados para Austria deben pasar a formar parte de un reino independiente con el segundogénito del emperador al frente. Según el escritor, el objetivo final sería debilitar a los Habsburgo con miras a reconquistar militarmente los territorios que no habían pasado a Francia por tratado. Se advierte, además, a los estados italianos independientes del peligro de una Francia fuerte atrincherada en Nápoles y Sicilia, confinante con Saboya y con un príncipe satélite en Milán, situación que no tardaría en ser aprovechada por Luis XIV para hacerse dueño de toda la península. Aislados y rodeados los territorios de la península Ibérica, no sería difícil para Francia someter al archiduque Carlos y ocupar también España.

La propaganda literaria proaustriaca parece en ámbito italiano, y probablemente a causa de las fallidas gestiones diplomáticas, más agresiva que la francesa que, al menos en apariencia, cuenta inicialmente con un mayor soporte legal basado, fundamentalmente, en el propio testamento de Carlos II. En este sentido, y de forma inmediata al fallecimiento del Habsburgo español, aparecen ya traducidas las cláusulas testamentarias que concretaban claramente la sucesión en Felipe de Borbón. ${ }^{8}$ Estas afirman que tras la ponderación de los

8. Capitoli del Real Testamento che formò alli 3. D'Ottobre 1700. La S. R. M. del Re Cattolico delle Spagne Carlo II, di gloriosa e felice ricordanza, spettanti alla Successione di tutti $i$ suoi Regni, e Signorie, Roma, nella stamperia di Gio Francesco Buagni, 1700 (Biblioteca Casanatense). 
consejos de diversos ministros de Estado y Justicia y la consideración de las renuncias de doña Ana y María Teresa de Austria, reinas de Francia y tía y hermana de Carlos II respectivamente, se ha decidido la unión de la monarquía hispánica con la corona francesa de acuerdo con las leyes del reino que dan razón al derecho de sucesión en el pariente más directo. Esta relación de parentesco se verifica en el segundogénito del delfín de Francia, por lo que Carlos II proclama al duque de Anjou heredero de todos sus reinos y dominios sin excepción alguna. Es voluntad del rey, igualmente, que en bien de la cristiandad entera, la monarquía hispana se mantenga siempre separada de la francesa, por ello se estipula que, en caso de fallecimiento del duque de Anjou o en el supuesto que el primogénito del delfín de Francia muriera y pasara por tanto a Anjou la corona francesa, el trono español sea para el duque de Berri, hermano menor de los antes mencionados hijos del delfín de Francia.

Se establece que, en el caso de fallecer Carlos II de Austria, rey de España, sin descendencia directa, se alcen inmediatamente las armas de Felipe de Borbón como nuevo monarca según el uso y costumbre de cada uno de los reinos y territorios de la monarquía hispánica.

Tras la muerte de Carlos II y la apertura de su testamento que proclamaba único heredero a Felipe de Borbón, la aceptación por parte de Luis XIV del documento y la renuncia, por tanto, al Tratado de la División, se reorienta la propaganda antifrancesa de manera inmediata $y$, de nuevo falsamente en Colonia, se publica la segunda parte de Lo spartimento del favoloso leone. ${ }^{9}$ Ahora, tan solo un año después, la estrategia del bando austriaco se centra en describir las estratagemas urdidas por Luis XIV para sentar en el trono español a Felipe, duque de Anjou.

El texto comienza atacando el ardid de Luis XIV al pretender que con la entronización de Felipe de Borbón Francia salía perdiendo, pues renunciaba a incorporar a la corona todos los territorios que le hubieran correspondido según el Tratado de División. Al mismo tiempo el monarca francés ha difundido la teoría de que la unión de ambas monarquías bajo los Borbones resulta fundamental para contener la difusión de la herejía. Según el relator, basta con hacer memoria para enumerar las afrentas de la corona francesa al difunto Inocencio XI, aunque lo que esclarece la posición francesa con respecto a la religión católica de manera más clara son sus constantes alianzas con el Imperio otomano. Se exalta, por contra, el papel de la Casa de Austria en su rama no española como defensora nata de la fe católica. Los Habsburgo, respetando el carácter electivo del Imperio, se han mantenido al frente del mismo como única dinastía católica cuyas posesiones hereditarias la dotaban de un poder suficiente como para liderar tan amplio conjunto de estados. Sus constantes guerras contra el turco la han convertido, además, en el principal opositor a los musulmanes y en defensa de Europa ante su avance.

9. Lo spartimento del favoloso leone verificato dal Rè di Francia nell'intrusione del Duca d'Angiò alla Corona di Spagna, con il giusto diritto dell'Imperadore, e della sua Casa a questa Corona. Parte seconda, Colonia, 1701 (Biblioteca Casanatense). 
Se responde a las acusaciones francesas de pretensión de una monarquía universal por parte de los Habsburgo. En este sentido se señala cómo, en la historia reciente, Francia se ha caracterizado por un agresivo expansionismo territorial, mientras que España, en franca decadencia, ha ido retrocediendo ante las imposiciones francesas. El Imperio, por su parte, se ha limitado a defenderse de los ataques musulmanes en el este y a intentar proteger la frontera occidental de Alemania de los constantes ataques de Luis XIV.

Por ello, se previene a los territorios de la corona española del peligro francés. Las tropas del duque de Anjou han ocupado ya España y Milán, y se aprestan a descender hacia el sur sabiendo que nada se interpone en su camino hacia el dominio de Nápoles y Sicilia.

Se pasa, a continuación, a enumerar las razones, legales y de justicia natural, que sustentan el asentamiento del archiduque Carlos en el trono de España como Carlos III. Como resultará leitmotiv en la propaganda habsbúrguica, los puntos sobre los que se hace palanca son las renuncias de las infantas españolas y reinas de Francia, Ana y María Teresa de Austria, así como los testamentos de Felipe III y Felipe IV. Sin embargo, el centro del discurso en este caso lo constituye la revisión del árbol genealógico de los Austrias.

Se afirma la legitimidad de Felipe el Hermoso, casado con Juana la Loca, como rey de España, tanto de Castilla como de Aragón. Se establece, por otro lado, la separación de las ramas española y alemana a partir de Felipe el Hermoso, entre sus hijos Carlos y Fernando. La clarificación subjetiva de este período de la dinastía Habsburgo contiene una sutil intencionalidad destinada a fortalecer el carácter de Felipe I como primer rey de España de la familia Habsburgo y, por tanto, marcar los lazos entre las dos ramas de los Austrias. Se pasa solo de puntillas sobre el hecho de que Felipe fue solo rey consorte y que la división de las posesiones sería fruto de Carlos V.

La genealogía demostraría, pues, que Leopoldo es el legítimo sucesor de Carlos II debido a las renuncias de las infantas reinantes en Francia. Además, Leopoldo es hijo de María de Austria, hija de Felipe III y no excluida de la sucesión española en el contrato matrimonial con Fernando III. Por otro lado, se presenta como prueba de las intenciones hispanas de mantener la primacía de la casa de Habsburgo en las sucesiones el hecho de que, cuando los reyes de España han casado a sus hijas primogénitas con monarcas franceses, han estipulado siempre cláusulas de renuncia a sus derechos sucesorios, mientras que cuando el matrimonio se ha celebrado con emperadores austriacos no ha sido así. De este modo se aprecia en los matrimonios de las dos hijas de Felipe III, Ana y María, casadas respectivamente con Luis XIII de Francia y Fernando III de Austria, o en los de las hijas de Felipe IV con Luis XIV y Leopoldo de Austria.

Se transcribe en este punto el acta de renuncia de María Teresa de Austria a sus derechos hereditarios sobre la corona española al casarse con Luis XIV de Francia. Se responde así a un «falso español» que ha afirmado que el único 
motivo de estas cláusulas era evitar la unión de las dos coronas y que este punto se subsanaba solo con otorgar la española al duque de Anjou que, al no ser primogénito, no heredaría la francesa. Se afirma que estas cláusulas fueron introducidas para establecer una relación de igualdad en los matrimonios, ya que las infantas francesas están legalmente excluidas de la sucesión a la corona. Además, la intención de descartar exclusivamente a Francia de la sucesión española es refrendado, en el caso de María Teresa, por el hecho de que su renuncia queda restringida a su carácter de reina francesa, volviendo a adquirir todos los derechos en caso de enviudar y casarse nuevamente.

Por ende se refuerza la exclusión francesa mediante el articulado de los testamentos de Felipe III y Felipe IV. Se responde, asimismo, a la afirmación francesa de que tanto los pactos matrimoniales como los testamentos de los dos Felipes van en contra del Derecho, y se retrotrae, para ello, hasta las sucesiones establecidas en la Antigüedad bíblica por las tribus de Israel.

Se pasa a continuación a abordar uno de los temas más espinosos de la cuestión sucesoria que afecta negativamente a la causa austriaca y que será muchas veces obviado por sus partidarios, el del testamento de Carlos II. Este se declara nulo y se supone falso o extraído por la fuerza del difunto rey. La amenaza francesa de desmembramiento de los estados que componen la monarquía española habría situado a Carlos II en una posición similar a la de las madres ante Salomón, de modo que el monarca habría preferido perder los territorios hereditarios de los Habsburgo antes que ver como los despedazaban.

Según el redactor del texto, Carlos II tenía intención de designar al Archiduque Carlos como su sucesor, y así lo prueba el carteo mantenido con el emperador Leopoldo. Del mismo modo, en esta dirección se orientan los movimientos de tropas que durante los últimos años de vida del monarca se realizan por parte de las tropas españolas e imperiales de mutuo acuerdo. Se destaca el papel del duque de Moles, embajador español en Viena, en las conversaciones desarrolladas para asegurar la sucesión española dentro de la familia Habsburgo. ${ }^{10}$

Se acusa al partido francés en Madrid de haber incomunicado al rey durante sus últimos días de vida y haber extraído de un moribundo la firma de su última voluntad contradiciendo el testamento que previamente había firmado en favor del archiduque Carlos. De hecho, el testamento se abrió ante un reducido grupo de miembros del partido francés, negándose la presencia al embajador imperial o al cardenal Portocarrero.

Se hace referencia, además, a las diferentes leyes que rigen en cada uno de los reinos de la monarquía hispana y que hacen imposible la sucesión del duque de Anjou en Aragón, Milán, Países Bajos, Nápoles y Sicilia, en atención a las leyes sucesorias del primero y al hecho de estar enfeudados a favor del emperador y el papa el resto.

10. Con respecto a este tema también será publicado el Manifesto del Duca Moles, già ambasciatore di Carlo II Re di Spagna, alla Corte Cesarea, sin lugar ni fecha de edición (Biblioteca Casanatense). 
Se usa como prueba de la manipulación del testamento de Carlos II por parte de Francia un punto que resulta de especial interés. En el documento se dedica una buena parte del articulado a establecer el Consejo de Regencia que habría de gobernar España en caso de que el monarca muriera mientras su sucesor fuera aún menor de edad. La mayoría de edad para acceder a la corona española se fijaba entonces en los catorce años, mientras que en el momento de la firma del testamento el duque de Anjou es casi tres años mayor. El archiduque Carlos, sin embargo, era dos años más joven que el francés y, por ello, se considera que el testamento que se obligó a firmar a Carlos II era, en realidad, un documento preparado para fijar la sucesión en el pretendiente Habsburgo cuyo nombre se eliminó, pero no así determinadas cláusulas que solo tenían sentido en el caso de ser Carlos el elegido.

Por último se exponen los perjuicios que para España y Europa está empezando a suponer la presencia del duque de Anjou en la península Ibérica. Para empezar, el duque, al que se compara con Tarquino el Soberbio, se ha trasladado a Madrid con toda una corte francesa, marginando a los españoles del gobierno y comenzando una carrera imparable hacia la tiranía, siguiendo el modelo francés e ignorando por completo las leyes y usos de los reinos de España. Se prevé el afrancesamiento de España con la introducción de modas y costumbres del país galo que darán paso a la corrupción y la licencia. Se advierte, asimismo, que la reivindicación armada de sus derechos por parte de Leopoldo será, sin duda, aprovechada por Francia para entrar militarmente en España y someterla.

La prevención a Europa entera se centra, en fin, en hacer ver las pretensiones universales de la monarquía francesa que, cuando haya establecido su imperio en España, Italia y los Países Bajos, comenzará el ataque de Alemania con el pretexto de extirpar la herejía, como ya permiten intuir las declaraciones y movimientos de Luis XIV. Se exhorta, así mismo, al pueblo español a rebelarse y a dejar de ser esclavos de Francia para volver a ser dueños de sus reinos y a todos los estados europeos a unirse contra Francia.

Los ataques a la toma del poder en España por Felipe de Borbón irán subiendo de tono y en ellas se entremezclarán las compilaciones legales destinadas a refutar las pretensiones francesas con invocaciones divinas de carácter casi mesiánico. Sirva como ejemplo el libro Il giudicio d'Europa que, ${ }^{11}$ elaborado como una farragosa compilación de leyes, tratados y testamentos destinados a apuntalar las razones de Leopoldo I, emplea en su portada el Salmo 42, Judica me Deus, et discerne causam meam de Gente non Sancta, ab homine inique et doloso erve me. Las reivindicaciones austriacas, ignorando el testamento de Carlos II, se concretarán, finalmente, en el solemne acto de

11. Il giudicio d'Europa nella gran causa della libertà comune, per quelle ragioni che tiene la S.C.R.M. di Leopoldo I Imperatore de'Romani sopra la monarchia di Spagna, insidiosamente occupata da' Galli, sin lugar ni fecha de edición (Biblioteca Casanatense). 
cesión de la Corona de España por parte de Leopoldo a su hijo Carlos el 12 de septiembre de 1703 del que también en Italia se publicará una relación. ${ }^{12}$

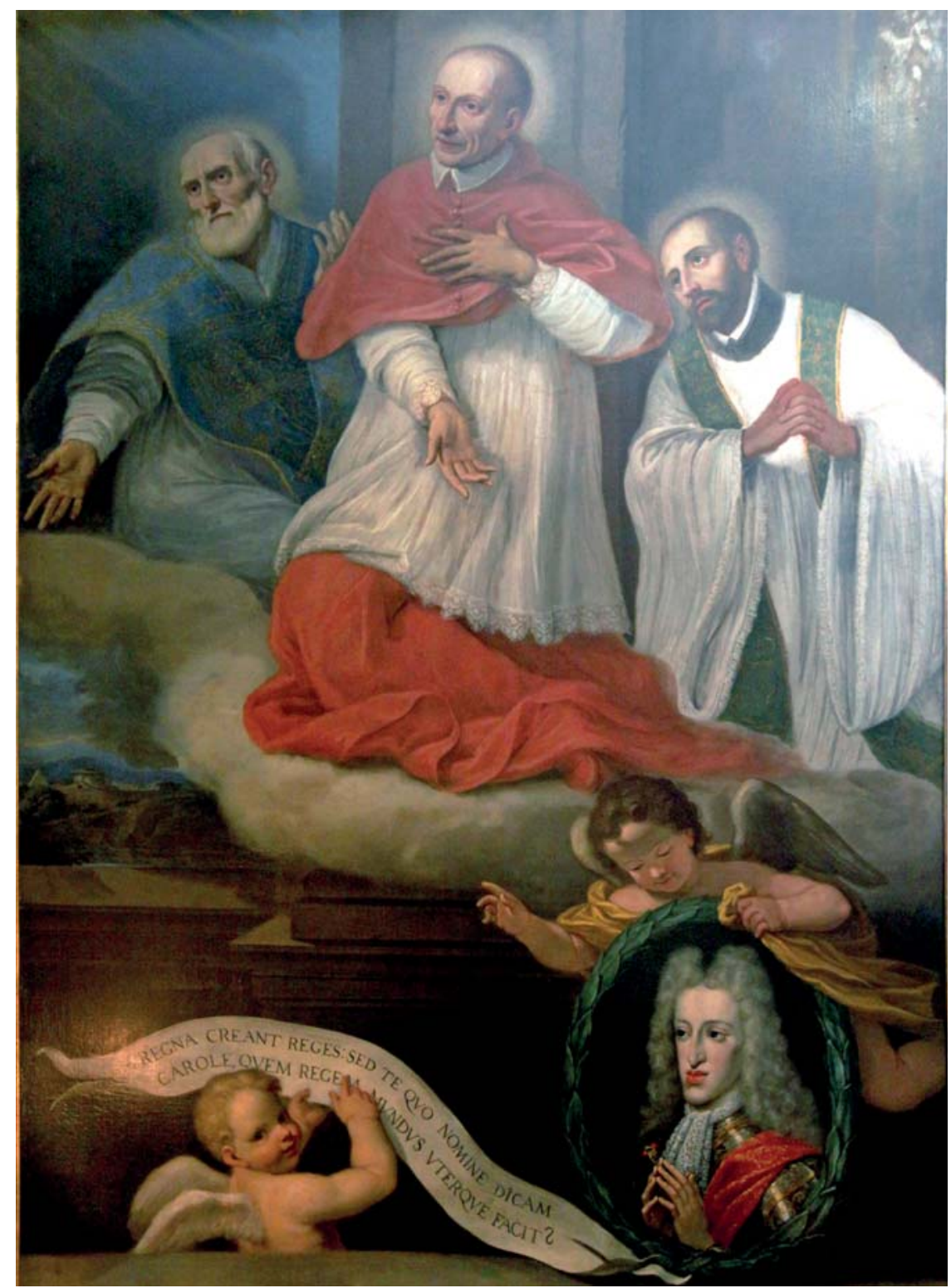

Fig. 5. Giacinto Calandrucci?, Carlos II y los Santos Juan Bautista, Juan Evangelista y Santiago el Mayor, iglesia de Santa Bibiana, Roma

12. Succinta, e distinta relatione dell'atto di cessione fatta dalla Maestà Cesarea, e Re de Romani in Persona del Serenis. Arciduca CARLO, e della Successione nella Monarchia di Spagna, sin lugar ni fecha de edición (Biblioteca Casanatense). 


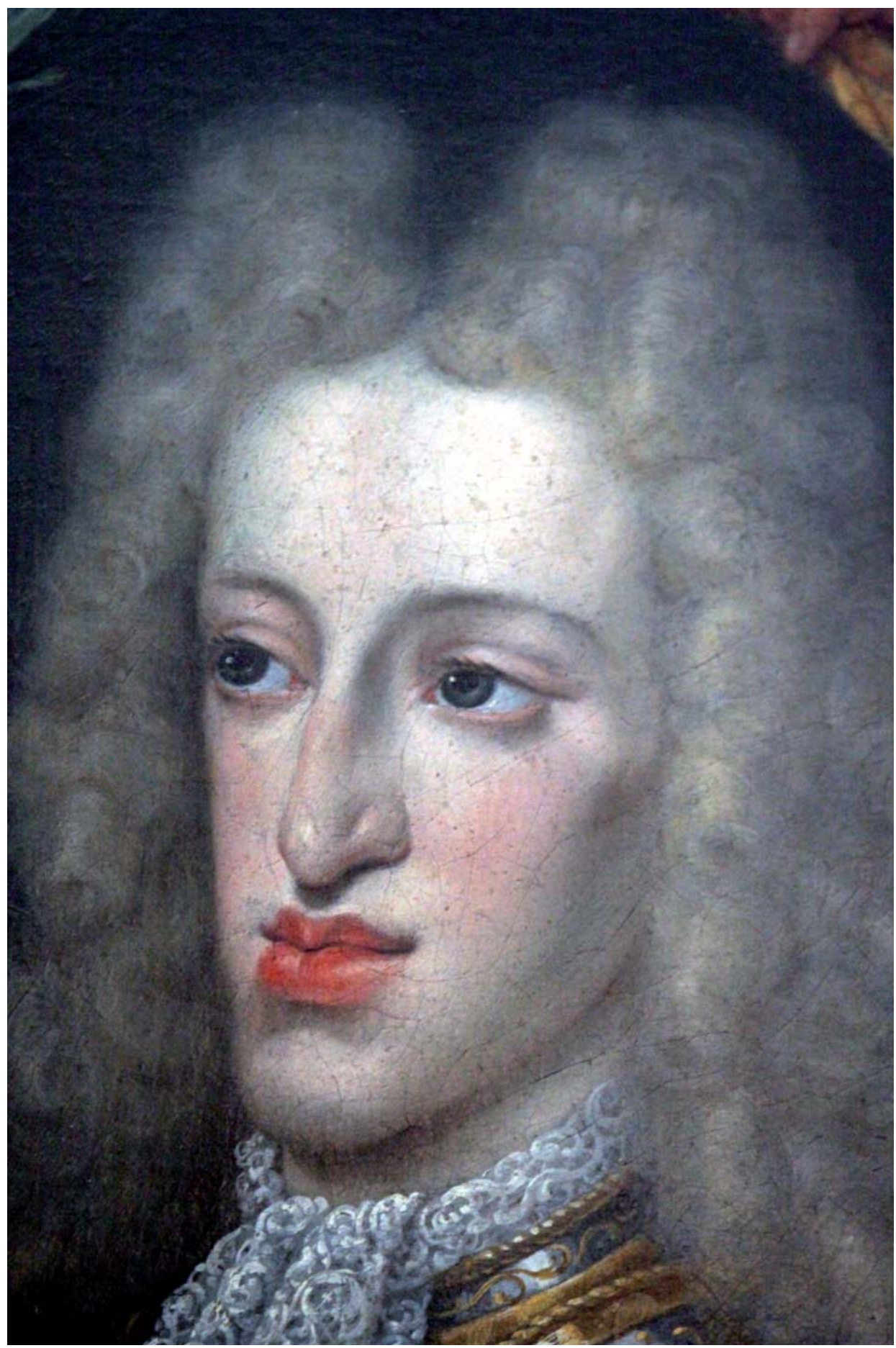

Fig. 6. Giacinto Calandrucci?, Carlos II y los Santos Juan Bautista, Juan Evangelista y Santiago el Mayor, iglesia de Santa Bibiana, Roma (Detalle) 
La lucha de los textos, a veces acompañados de grabados, encuentra su plasmación más directa en al ámbito de la imagen en dos cuadros que fueron dados a conocer hace décadas por Elías Tormo, ${ }^{13}$ pero sobre los que solo

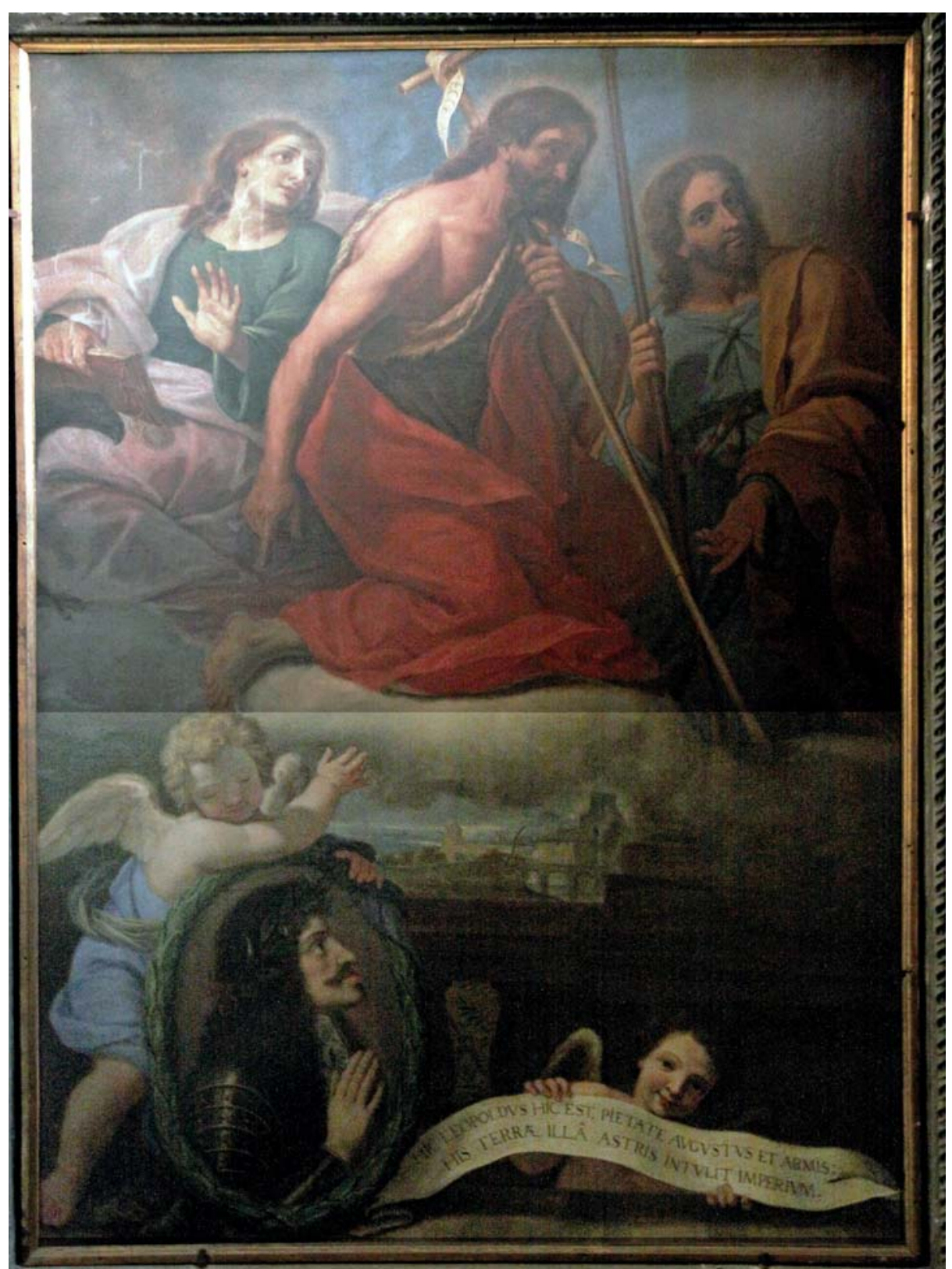

Fig. 7. Giacinto Calandrucci?, El Emperador Leopoldo y los Santos Carlos Borromeo, Felipe Neri y Francisco Javier, iglesia de Santa Bibiana, Roma

13. Tormo, Elías, Monumentos de españoles en Roma, y de portugueses e hispano-americanos, Ministerio de Asuntos Exteriores, Madrid, 1942, tomo II, pp. 115-116. 
recientemente se ha investigado en profundidad y se ha puesto en valor su importancia en el contexto político de los primeros años del siglo XVIII. ${ }^{14}$ Las pinturas a las que se hace referencia componen el conjunto decorativo de una capilla en la iglesia romana de Santa Bibiana. Se trata de tres cuadros encargados, como se ha documentado, por un canónigo de la basílica de Santa María la Mayor, templo del que dependía la actual parroquia de Santa Bibiana hasta el siglo xx. En el altar mayor se representó la adoración del icono conocido como Madonna Paolina por los santos Flaviano, Fausto y el presbítero Juan y, a los lados, se ubicaron dos lienzos con los retratos del emperador Leopoldo I y el rey Carlos II acompañados, respectivamente, por los santos Juan Bautista, Juan Evangelista y Santiago el Mayor, y Carlos Borromeo, Felipe Neri y Francisco Javier. El programa iconográfico, realizado en un breve lapso de tiempo y concebido de forma unitaria, parece datarse entre 1700 y 1702 y para su autor, aunque no documentado, se ha indicado el nombre de Giacinto Calandrucci.

El interés del programa iconográfico, aparte del tema central de la exaltación de la Virgen y los santos, con una preeminencia de los hispanos, se centra en la aparición de los dos retratos en medallones. Estos están acompañados de dos filacterias en las que se lee, junto a Leopoldo I, Hic Leopoldus Hic Est Pietate Augustus et Armis: His Terrea, Illa Astris Intulit Imperium, y junto a Carlos II, Regna Creant reges sed te quo Nomine Dicam Carole Quem Regem Mundus Uterque Facit? La cartela que acompaña al emperador exalta su piedad y su carácter guerrero, en cambio la de Carlos parece algo más problemática. En este texto, planteado de manera interrogativa, tras afirmar que los reinos crean a los reyes, el redactor se pregunta cuál será el nombre que se dará a Carlos, que reina sobre dos mundos.

Además de lo críptico de la filacteria que acompaña al retrato de Carlos II, otro punto problemático es la datación de las pinturas. Si efectivamente estas fueron realizadas entre 1700 y 1702, la imagen de Leopoldo correspondería a un vivo, ya que este no fallece hasta 1705, mientras que la del último Habsburgo español se trataría de un retrato post mortem. Este punto, unido a la coincidencia de nombre entre Carlos II y el archiduque Carlos, hijo de Leopoldo, ha llevado a los recientes estudios a preguntarse si la cartela que acompaña al monarca español no pudiera estar referida al pretendiente austriaco en la guerra de Sucesión, sugerente hipótesis que incluiría en el conjunto decorativo de Santa Bibiana a un tercer personaje, no retratado mediante imagen pero sí en texto.

Independientemente de la interpretación de la cartela que acompaña al magnífico retrato de Carlos II, el punto fundamental del programa decorativo es la exaltación dinástica de los Habsburgo y su inclusión dentro del amplio

14. Garms-Cornides, Elisabeth, «Spanischer Patriotismus und «Österreichische» Propaganda. Habsburger-Porträts in einer römischen Kirche aus der zeit des spanischen Erbfolgekriegs», Romischer historische mitteilungen, 31, 1989, pp. 255-282. A conclusiones similares llega PASCUAL CHENEL, ÁlvARO, «Un controvertido retrato de Carlos II en Roma», Archivo Español de Arte, LxxxiI, 327 (julio-septiembre 2009), pp. 308-315. 
programa de propaganda gestado en torno a la cuestión sucesoria. Esta pequeña capilla, encargada por un canónigo español, cobra especial significado dentro de un templo que es en sí una prolongación de la basílica de Santa María la Mayor. Esta basílica estaba, desde hacía décadas, bajo el patronazgo directo de los reyes de España, que la dotaron generosamente y la convirtieron en parte del aparato de representación de la monarquía hispana en la ciudad papal. Así, cuando uno accede al nártex que precede el templo, la primera imagen que recibe al visitante en la basílica liberiana es la escultura de bronce de Felipe IV que, como un emperador romano, aparece solemne a la derecha del que entra. ${ }^{15}$ Del mismo Felipe IV se celebrarían en la iglesia solemnes exequias con gran pompa, ${ }^{16}$ y lo propio se organizaría para los funerales de Carlos II, ${ }^{17}$ lo que muestra la continua vinculación del clero de esta basílica mayor con los sucesos que atañen a la monarquía española. Por tanto, no sorprende que la aparición en Roma de un programa iconográfico centrado en la monarquía española se produzca en un espacio propiedad de la basílica de Santa María la Mayor.

Una vez centrada la iconografía y la ubicación de este conjunto pictórico procede plantearse su interpretación y la posibilidad de que el encargo de esta amalgama de imágenes y textos se incluya dentro de la particular coyuntura histórica de la Roma de 1700. Como se ha expuesto, desde finales del siglo XVII, y ante la inminencia de la muerte de Carlos II sin descendencia directa, los partidarios de fijar la sucesión a la Corona española en los Habsburgo austriacos desarrollan en Italia, y en concreto en Roma, una constante labor propagandística a través de los textos y las imágenes. Esta campaña, destinada a sustentar las pretensiones del archiduque Carlos, hijo del emperador Leopoldo I, se centrará, además de en los ataques a Francia más o menos justificados, en resaltar la unidad de las dos ramas de los Habsburgo, para contrarrestar, mediante motivos éticos o emotivos, la mayor consanguineidad de los monarcas franceses con respecto a los Habsburgo españoles. Así lo muestran las constantes referencias al tronco común de las familias y la apelación a Carlos V como padre de ambas estirpes. Dentro de esta presentación de las dos ramas de los Habsburgo como una unidad indisoluble es donde se encuadra la decoración pictórica de la capilla de Santa Bibiana. Independientemente de que el observador acepte más o menos la inclusión implícita del archiduque Carlos dentro del conjunto, lo que resulta evidente es que los cuadros de Calandrucci

15. Véase al respecto Bodart, Diane H, «La guerre des estatues. Monuments des rois de France et d'Espagne à Rome au XVIIe siècle», en Roma y España. Un crisol de la cultura europea en la Edad Moderna, Sociedad Estatal para la Acción Cultural Exterior, Madrid, 2007, pp. 679-694.

16. Relatione delle sontuose esequie fatte dall' Illustrissimo e Reverendissimo Capitolo, e Canonici della Sacrosanta Basilica di Santa Maria Maggiore in Roma, alla gloriosa memoria di Filippo IV Re delle Spagne con alcune osservationi sopra i particolari del funerale, Roma, per Giacomo Dragondelli, 1666 (Biblioteca Casanatense).

17. Relazione dell'esequie reali fatte nella Sacro-Santa Basilica di S. Maria Maggiore in Roma a di 22 gennaro 1701 per il già Rè delle Spagne Carlo II di sempre gloriosa memoria, Roma, nella stamperia di Antonio de Rossi, 1701 (Biblioteca Nazionale Centrale Vittorio Emanuele II). 
muestran a quien se acerca un retrato de familia. Leopoldo y Carlos, monarcas católicos, oran juntos a la Virgen, patrona de la basílica de Santa María la Mayor. Ambos, miembros de una misma dinastía, se presentan como devotos defensores de la religión bajo sus santos protectores y, lógicamente, si uno de ellos falleciera, como de hecho ha sucedido en el momento en que se pintan sus imágenes, el otro ocuparía el lugar vacante.

Se nos muestran, de este modo, los retratos de dos monarcas de una misma familia que, por ende, comparten hasta los defectos físicos como el prognatismo, y es en esta unión indisoluble de la dinastía Habsburgo donde cobra sentido el acto de cesión que Leopoldo hace de la monarquía hispana a su hijo Carlos. Una pieza más, aunque probablemente la más hermosa, en una cuidada orquestación propagandística en la que casi ningún fleco parece dejado al azar. Y en este sentido resulta paradigmática la elección del pintor que plasmaría los retratos de ambos Habsburgo, Giacinto Calandrucci. Calandrucci era un pintor de segunda fila en el medio romano de en torno a 1700 , pero, sin embargo, es pintor predilecto de la comunidad portuguesa en Roma, para la que pinta, entre otros, el altar mayor de su iglesia nacional de San Antonio, y Portugal sería uno de los principales aliados del archiduque Carlos en la guerra de Sucesión a la Corona española.

A pesar de la actitud un tanto ladina del Papado a la hora de reconocer los derechos de cualquiera de los pretendientes sobre los territorios italianos de la monarquía española, ${ }^{18}$ en los primeros años del siglo xvin Felipe de Borbón entra en Italia para tomar posesión de los mismos y da lugar a una gran cantidad de literatura impresa sobre los festejos celebrados durante sus ingresos triunfales. ${ }^{19} \mathrm{Al}$ mismo tiempo comienzan a aparecer obras impresas que se defienden de los ataques orquestados por el bando austriaco. En ellos se hace hincapié en el factor genealógico que, indudablemente, favorece las pretensiones francesas. Así, en textos como Riflessioni sopra i diferenti interessi, che la maggior parte delle Potenze d'Europa hanno nel presente stato della Monarchia di Spagna, ${ }^{20}$ se recuerda que las leyes sobre herencia de España

18. Taвacchi, Stefano, «L'impossibile neutralità. Il Papato, Roma e lo Stato della Chiesa durante la Guerra di Successione Spagnola», Cheiron, 39-40, 2003, pp. 223-243.

19. Solo en Nápoles se registran, al menos, cuatro panfletos. Distinta relazione della cavalcata, e solenni cerimonie, per l'acclamazione del nostro Glorioso Monarca Filippo V. Celebrate dall'Eccellentissimo Sig. D. Luigi della Cerda e Aragona, Duca di Medinaceli e Vicerè e Capitan Generale in questo Regno, Napoli, 1701. (Biblioteca Nazionale Centrale Vittorio Emanuele II), Distinto racconto della Real Cavalcata fatta dai Titolati, Cavalieri, e Baroni di questo Regno, tra quali tre Cardinali, molti Principi, e Signori Romani, con tutte le sollennità, che in Funzioni cosi grandi accostumansi. Per l'ingresso in questa fedelisima Città di Napoli del nostro Gloriosissimo Monarca Filippo V, Napoli, per Giovanni Roselli. (Biblioteca Casanatense), Distinta relazione e sincero ragguaglio del solenne ingresso fatto in Napoli per dar la benvenuta a' nome di Sua Santità al nostro glorioso monarca Filippo Quinto dall'eminentissimo Carlo Barberino, Napoli, per Dom. Ant. Parrino, 1702. (Biblioteca Casanatense) y Altra lettera scritta da Antonio Bulifon a un suo amico: nella quale gli da ragguaglio della seconda Cavalcata fatta in Napoli per la solenne entrata dellEminentiss. Sig. Cardinal Carlo Barberini mandato da sua Santità in qualità di suo Legato a latere a Filippo V monarca delle Spagne, Napoli, nella stamperia di Felice Mosca, 1702. (Biblioteca Casanatense).

20. Riflessioni sopra i diferenti interessi, che la maggior parte delle Potenze d'Europa hanno nel presente stato della Monarchia di Spagna, sin lugar ni fecha de edición (Biblioteca Casanatense). 
establecen que a la muerte del monarca la corona se transmita en primer lugar por línea masculina y en segundo por primogenitura. Así, Felipe IV fue sucedido por su único hijo varón vivo en el momento de su fallecimiento, siendo su hermana primogénita María Teresa, reina consorte de Francia y su hermana segundogénita María, emperatriz consorte de Alemania. María Teresa tuvo con Luis XIV al actual delfín de Francia que ha engendrado numerosos herederos, mientras que María solo tuvo una hija con Leopoldo que casó con el elector de Baviera con el que solo tuvo un hijo fallecido en 1699. Por lo tanto, los únicos descendientes de Felipe IV serían los descendientes de su hija María Teresa, miembros de la casa real francesa. La misma situación se da al retrotraerse una generación, ya que la madre de Luis XIV de Borbón fue la hija de Felipe III, Ana de Austria. Aún contando con las renuncias sucesorias de las dos infantas españolas casadas con monarcas franceses, el testamento de Carlos II en favor del duque de Anjou, Felipe V, no deja lugar a dudas.

El redactor de este texto se defiende de las acusaciones vertidas sobre las pretensiones de Luis XIV de instaurar una monarquía universal, que han hecho que Inglaterra y Holanda se sitúen al lado del Imperio. Contradice este rumor el hecho de que el rey de Francia, al aceptar el testamento de Carlos II, ha renunciado a las ventajosas condiciones que obtenía por el Tratado de la División, ya que ningún territorio de la monarquía hispana pasará a la gala. Sin embargo, ha sido aceptado para atenerse a la ley y no desmembrar una potencia como la española. Se ataca el imperialismo de la dinastía Habsburgo que, tras deponer el carácter electivo del Imperio, ha hecho y deshecho a su voluntad en los estados que lo conforman, pisoteando los privilegios y las leyes y grabando onerosamente a los gobernantes de sus estados. Se insta a los príncipes a unirse en contra del emperador y limitar así el aumento de sus fuerzas y su opresión.

$\mathrm{Al}$ mismo tiempo que Francia comienza su contraataque propagandístico, y de forma complementaria a la reivindicación de sus derechos sobre la herencia de Carlos II, también se publican algunos panfletos que de alguna manera justifican la entrada en guerra por parte de Felipe de Borbón contra el resto de potencias europeas, respondiendo de este modo a las acusaciones que, desde hacía años, había vertido el bando austriaco acerca de las continuas guerras a las que sometía el país galo al resto de potencias por el único motivo de su ambición. Así, encontramos escritos como Ragioni della guerra del Re Cattolico contro il Re di Portogallo, l'Arciduca Carlo di Austria, e i suoi alleati donde la guerra, como aplicación de la justicia, se plantea como legítima para los monarcas, aunque debido a las cargas que supone para los vasallos resulta conveniente explicar las razones que la motivan. ${ }^{21}$

El autor del texto narra cómo en función del testamento de Carlos II su sobrino el duque de Anjou ha accedido al trono español como Felipe V.

21. Ragioni della guerra del Re Cattolico contro il Re di Portogallo, l'Arciduca Carlo di Austria, e i suoi alleati, sin lugar ni fecha de edición (Biblioteca Casanatense). 
Como rey de España ha sido recibido en todos los dominios de la monarquía y todos los reinos le han jurado fidelidad. El papa lo reconoce como legítimo monarca, y lo mismo hacen el rey cristianísimo Luis XIV, Inglaterra, Holanda, los principados y repúblicas de Italia, la mayor parte del norte y Portugal. Sin embargo, Portugal, Inglaterra y Holanda han abandonado su alianza con Felipe V para crear una nueva alianza con el emperador Leopoldo I para entronar al archiduque Carlos. Con estas pretensiones ha comenzado el desmembramiento de los territorios de la monarquía, habiendo cedido la Casa de Austria a Portugal las plazas de Badajoz, Alcántara, Alburquerque y Valencia en Extremadura, Bayona, Vigo y Tui en Galicia, y todo lo que queda más allá del Río de la Plata en las Indias Occidentales. Portugal, además, ha introducido al archiduque en territorio español rompiendo todas las convenciones internacionales, por lo que Felipe V se ve obligado a declarar la guerra a Portugal, al archiduque y a sus aliados por la Fe, por la Corona y por el Honor de la Patria.

El recrudecimiento de los enfrentamientos militares y la entrada de Francia en el intercambio de ataques literarios y gráficos generarán, en pocos años, la aparición de una verdadera avalancha de pequeñas publicaciones incitando a los lectores a decantarse por un bando o el otro. De entre este caudal textual, de empeño y calidad muy desigual, surgirá un verdadero juego cruzado que, en ocasiones, dará lugar a auténticas joyas literarias que se contestan descaradamente unas a otras..$^{22}$ Así, en 1702, se publica la Lettera seria ad un amico ${ }^{23}$ que comienza dirigiéndose a un presunto interlocutor que ha reprendido al redactor del texto por la vehemencia en la defensa de la justicia de la causa de Felipe $\mathrm{V}$ ante el irracional ataque de las armas austriacas. A la petición de ecuanimidad a la hora de valorar las razones de ambos contendientes en torno al problema de la sucesión a la Corona española tras la muerte de Carlos II, el remitente de la carta responde que su actitud está sobradamente meditada y responde a la certeza moral y al conocimiento de la verdad. Se desestima igualmente la motivación política que algunos aducen para sostener esta guerra afirmando que su objetivo es evitar la excesiva acumulación de poder por parte de la casa de Borbón, y proclamando que, además de ser esta motivación falsa, jamás un buen cristiano podría usar la política como razón para cometer una injusticia.

La exposición se maneja como una explicación basada en la lógica, casi un silogismo. Se afirma que, si la situación de enfrentamiento se hubiera producido años atrás, antes de los últimos sucesos, hubiera sido lógico que los espectadores como el que escribe se mantuvieran al margen y dejaran a

22. El carácter dialogante de los textos será una constante. Véase, por ejemplo, Martín VelasCo, MARGARITA, «La documentación histórica y la publicística del siglo xviII. Una insólita defensa de Felipe V: la respuesta del Duque de Uceda a un pasquín austracista difundido con motivo de la caída del Reino de Nápoles en 1707», Documentación de las Ciencias de la Información, 31, 2008, pp. 211-235.

23. Lettera seria ad un amico sopra l'affare dei tempi nel 1702, sin lugar ni fecha de edición (Biblioteca Casanatense). 
las partes exponer sus razones objetivas para sustentar las pretensiones a la corona española. Mientras los contendientes A y B mantengan sus posiciones ante $\mathrm{C}$, el espectador puede suspender su juicio aceptando por probabilismo que cualquiera de las dos opciones puede tener razones válidas. Sin embargo si $C$, juez supremo sobre la materia, tras consultar a multitud de ministros y consejeros, así como probablemente a gente ajena a la situación, que ha sido siempre amigo de A y enemigo de B, en el momento de rendir cuentas a Dios decide posponer la sangre y la amistad para sentenciar a favor de B, no se debe jamás dudar de la decisión tomada por este supremo juez. Esta es la certeza moral que lleva al redactor a defender la corona de Felipe V ante las pretensiones austriacas.

La certeza moral deriva, por otro lado, de las condiciones del juez que ha sentenciado entre las dos partes contendientes. Se trata de un juez de «legítima autoridad, único en la autoridad», porque la decisión es unipersonal, «supremo en el mundo», ya que no existe instancia superior a la que apelar, y es, por tanto, «inapelable». Se trata de una decisión inmutable, pues no fue tomada de manera apresurada sino tras infinidad de consultas y pronunciada por un juez incalumniable, ya que ha sido siempre amigo de A y enemigo de $\mathrm{B}$, además de ser «católico, religiosísimo y en estado de rendir cuentas a Dios de su sentencia».

Debido a una sentencia dotada de esta certeza moral es Felipe V rey de España, y en contra de una justa sentencia luchan las armas austriacas. Parece evidente que la sucesión a la Corona española ante la falta de descendencia de Carlos II no debería ser decidida ni por el Consejo Aúlico de Francia ni por el de Viena, ya que la monarquía española, siendo de por sí suprema, no depende de ninguno de los dos. Tampoco puede apelarse al juicio del papa ya que, por mucha autoridad que este tenga, nunca debe aplicarse esta de forma directa sobre lo temporal de los reinos, y no le corresponde de jure decidir la sucesión. Por lo tanto, el único que puede tomar la decisión sobre la sucesión a la Corona española es el Consejo Supremo de España con Carlos II al frente.

Se parafrasean aquí las cláusulas del testamento de Carlos II en las que, sin lugar a dudas, se designa al duque de Anjou como rey de España. El redactor de la carta analiza en este punto los componentes psicológicos del testamento de Carlos II a través del empleo del lenguaje para aclarar cualquier duda que pudiera existir sobre la legitimidad de las decisiones del monarca Habsburgo. Carlos, en la extensión de las cláusulas, solo emplea los verbos dejo y nombro cuando se refiere a los asuntos económicos relativos al propio patrimonio, que lega a Felipe de Borbón. Se establece así este como un acto volitivo en el que la voluntad del monarca define el destino de su herencia personal. Sin embargo, en las cláusulas que se refieren a la sucesión a los territorios de la corona hispánica no se expresa un acto de la voluntad sino de la razón, ya que Felipe no es elegido como heredero, sino que es el legítimo heredero. A esto se añade que todos los estados de la monarquía hispana se han sometido al duque de Anjou sin que haya sido necesario el empleo de una sola arma. 
Se mofa a continuación de la cantinela repetida de manera constante por los partidarios de las pretensiones de Leopoldo de Austria: la pertenencia de Leopoldo a la misma dinastía descendiente de Felipe I y Juana, la preferencia por la Casa de Austria en los testamentos de Calos V, Felipe II y Felipe IV, las renuncias de Ana y María Teresa de Austria, reinas de Francia..., para responder a todo ello basta la decisión incontestable de Carlos II.

Visto que el parentesco es válido tanto por vía masculina como femenina y, por lo tanto, la consanguineidad es mucho más próxima en el caso francés que en el de Leopoldo I y que los testamentos de Carlos V, Felipe II y Felipe IV no deben tomarse como modelo, ya que en nada se asemejan al presente caso y aquellos monarcas, de acuerdo con la ley, carecían de la potestad para disponer libremente de los reinos, se deduce que la renuncia de las reinas de Francia no afecta al caso, ya que la elección del duque de Anjou permite que la Corona española recaiga en una persona distinta a la que porta la de Francia. Visto todo ello, se ha decidido, y con decisión inapelable, que todas las acciones en contra de la designación de Felipe de Borbón son nulas por carentes de razón $\mathrm{y}$ fundamentos.

A continuación comienza la defensa contra el rumor de que el testamento de Carlos II pueda haber sido modificado de manera maliciosa sin su consentimiento para beneficiar a la casa de Borbón. El escritor se escandaliza ante la sugerencia de que este pecado mortal pueda haber sido cometido por personajes del rango de los ministros españoles o, aún más, por el cardenal Portocarrero. Defiende la imposibilidad de tal calumnia no solo por este motivo, sino por la presencia de la reina viuda Mariana de Austria, que jamás hubiera consentido, y por el sello y firma del documento que fue consignado ante notario público el tres de octubre, y el quince del mismo mes su codicilo.

Se rebate a continuación otro rumor, que contradice al primero, por el que el testamento en favor del duque de Anjou habría sido obtenido de Carlos II en el lecho agonizante de muerte con malas artes y sin valor alguno. Según el redactor de la carta el testamento fue entregado el dos de octubre en Medina al notario don Antonio de Ubilla, caballero de Santiago, consejero del rey, secretario de Estado para Italia y secretario del Despacho Universal. En estas fechas el rey se hallaba plenamente recuperado de la enfermedad de la que se vio aquejado en septiembre y no sería hasta noviembre cuando recaería en ella encontrando la muerte. Por lo tanto resulta inadmisible el rumor acerca de un testamento extraído fraudulentamente de un rey agonizante y privado de sus facultades mentales.

Existe, por otra parte, durante estos años, una teoría que afirma que, aun aceptando el testamento de Carlos II como juez supremo en lo que respecta a los reinos de España, el difunto monarca carece de esta autoridad en lo relativo a los reinos de Nápoles y Sicilia, que dependen de la Santa Sede, y al Estado de Milán, que depende del Imperio. Sin embargo, esta afirmación se rebate con la inalienabilidad de los territorios de la corona, así contemplada en las renuncias 
de las reinas de Francia y también en el testamento de Carlos II, en el que se nombran de manera específica Nápoles, Sicilia y Milán.

Aun quedando claro el carácter indivisible de la herencia del duque de Anjou, el relator de la carta se lamenta de que la Casa de Austria, en un intento desesperado de conseguir apoyo para sus pretensiones a la Corona española, ha hecho descender sus tropas a Italia para intimidar al papa. Si el emperador Leopoldo quisiera continuar con esta defensa de sus pretensiones sobre los territorios italianos, debería permitir al Papado tomar una decisión imparcial, y por lo que respecta a Milán, habría de ser el Consejo Electoral del Imperio (según lo jurado por Leopoldo en las Capitulaciones de Frankfurt) quien emitiera dictamen, también sin la presión militar a la que en estos momentos lo somete Leopoldo. De esta manera se vería claramente cómo Milán, desde Carlos V y Felipe II, no pertenece a la línea austriaca de la familia Habsburgo, sino que es territorio inalienable de la Corona española.

Para finalizar, se loa a Felipe V el Bello, el Amable, el Sabio, el Pío, el Elegido por Él (por Dios). La carta termina con un añadido en el que se expone que si en justicia cualquier persona debería, ante la claridad de lo expuesto, tener clara la sucesión al trono español en Felipe V, la injusticia del posicionamiento contrario resulta aún más flagrante en el caso de tratarse de súbditos de la Corona de España. En este caso se considera que toda persona que se oponga al duque de Anjou merecería no solo ser reo de muerte sino también la condenación eterna. Esto se deriva de la demostración de los legítimos derechos del Borbón. Si Carlos II era el legítimo rey, y nadie lo niega, rebelarse contra el heredero por él y por las leyes designado, supone la rebelión del vasallo contra su legítimo monarca y, debido a la personificación que Dios hace en el rey, supone rebelarse igualmente contra los designios divinos.

El texto en defensa de Felipe de Borbón debió tener contestaciones ya que, poco después, se publica un nuevo texto concebido como un contraataque ante los embates recibidos por la Lettera seria ad un amico. ${ }^{24}$ En este caso la redacción corresponde, en lugar de al género epistolar, a la forma de un diálogo teatral, y el centro del discurso lo constituye el tema que, junto al del testamento de Carlos II, se convertirá en el punto fuerte de la propaganda francesa, la mayor cercanía del parentesco de Felipe de Borbón con Carlos II. Por ello, la única imagen gráfica que se elige para ilustrar el discurso es un árbol genealógico de los reyes de España comenzando con los Reyes Católicos, estampa recurrente que aparecerá con frecuencia en la cultura impresa de principios del siglo XVIII. El hermoso grabado ilustra de forma sencilla la sucesión de las generaciones a partir de los primeros reyes de la España unificada dejando claro, con un solo golpe de vista, que el único descendiente

24. Dialogo naturale schietto, e famigliare tra Clerio e Ernesto sopra la Successione di Spagna, da servire d'Apologia contro le eccezzioni, che un Corrispondente hà raccolto essere state fatte alla Lettera seria scritta ad un Amico sopra l'affare de'tempi nel 1702, sin lugar ni fecha de edición (Biblioteca Nazionale Centrale Vittorio Emanuele II). 
directo vivo de un monarca español es la casa de Borbón. Esta imagen será empleada con frecuencia para ilustrar la justicia de la causa del duque de Anjou, mientras que los defensores del pretendiente austriaco, aún reclamando los derechos del archiduque Carlos, rehuirán la representación de un árbol genealógico que difícilmente podía ser manipulado a su favor. ${ }^{25}$

Sin embargo, y a pesar de que, objetivamente, la motivación genealógica está sin duda del lado de las pretensiones francesas, el grabado en que se concretan las líneas sucesorias no está exento de una intencionalidad sutilmente plasmada. Cada uno de los componentes del entramado sucesorio está inscrito dentro de un círculo y a su nombre se añaden, en ocasiones, apreciaciones que indican la inclinación de la mente que lo diseñó. Así, Juana la Loca aparece como Gioanna erede di Aragona e Castiglia, mientras que Felipe el Hermoso es definido como Filippo I di Austria. Marito di Gioanna. Se destaca de esta manera el papel exclusivo de consorte y, por lo tanto, sin derechos propios a la corona española, del primer Habsburgo emparentado con la monarquía hispana y, por ello, sus hijos Carlos y Fernando suponen la división, de facto, de las dos ramas de la familia, siendo solo la primogénita la que tiene derechos sobre España, directamente heredados de Juana. La descendencia de ambas ramas continúa siempre regida por este sutil matiz, aunque la apuesta más clara del ideador del árbol genealógico se encuentra en la última generación, la directamente relacionada con los contendientes en la guerra de Sucesión. Así, la leyenda del grabado indica que se marcarán con una cruz los puntos en que se extingue una línea sucesoria y, en el último escalón del árbol, se marca la extinción de dos líneas. La primera de las cruces se sitúa bajo el nombre de Carlos II, al que se le da el sobrenombre de El Justo y se destaca mediante una corona con la palabra Justitia, y marca el final de la dinastía de los Habsburgo españoles. La segunda cruz se ubica bajo el nombre del príncipe de Baviera que, con la cartela ut in coelis, indicaría la extinción de los sucesores directos de una rama colateral de los Habsburgo españoles a través de una de las hijas de Felipe IV. El archiduque Carlos, cuyo parentesco con la dinastía hispana no es directo, porta la cartela ad orientem, y es solo Felipe de Borbón, V de España y descendiente de los Habsburgo españoles, tanto de Felipe III como de Felipe IV, quien se destaca como legítimo monarca. Y así aparece resaltado con la cartela divino flamine y el toisón de oro pendiendo de su nombre.

25. Véase, por ejemplo, Jus Austriacum in Successione Regnorum Hispaniae vindicatum, 1704 (Biblioteca Casanatense). 


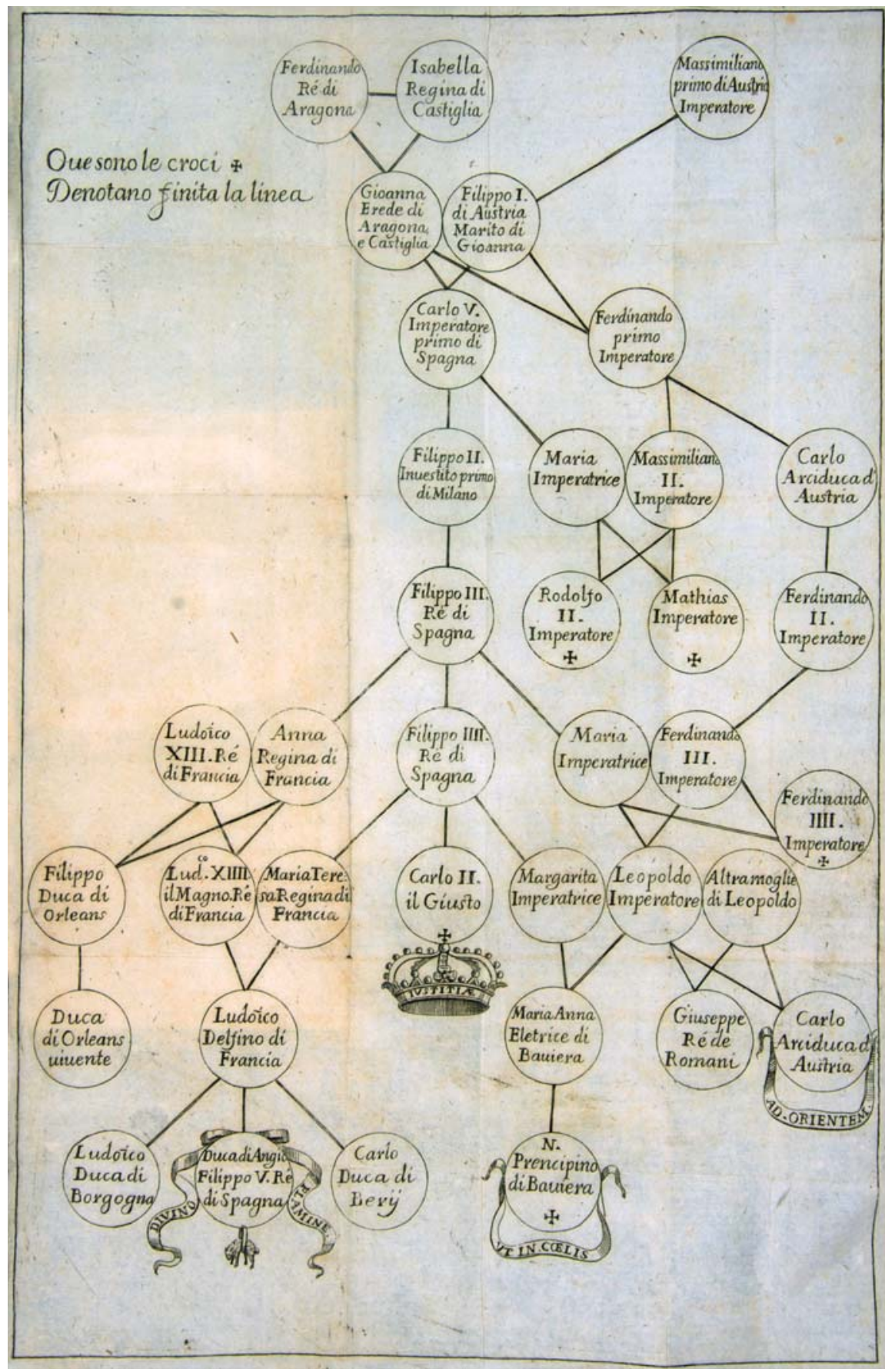

Fig. 8. Árbol genealógico de la monarquía española en Dialogo naturale schietto, $e$ famigliare tra Clerio e Ernesto sopra la Successione di Spagna, da servire d'Apologia contro le eccezzioni, che un Corrispondente hà raccolto essere state fatte alla Lettera seria scritta ad un Amico sopra l'affare de'tempi nel 1702. Biblioteca Nazionale Centrale Vittorio Emanuele II (Roma) 
La lucha más directa entre los partidarios de Austrias y Borbones se materializa, sin embargo, en dos textos de considerable extensión que alcanzarán gran difusión en el medio italiano. El primero de ellos es la Tromba $d^{\prime}$ Europa, ${ }^{26}$ que comienza haciendo referencia a la justicia divina en la figura de Saúl que, por su soberbia, fue duramente castigado por Dios, mientras que David, con culpas mayores, supo arrepentirse de sus errores. Se emplean, acerca del conflicto en ciernes, metáforas tendentes a afirmar que el martillo de la envidia francesa no hará sino destacar finalmente las virtudes de la causa austriaca y su actitud se compara con la de Lucifer y Caín.

De la historia de la monarquía francesa se defiende el catolicismo de sus primeros reyes, de Clodoveo a Pipino, pero se hace descender la tradicional ambición de esta casa real a la división entre los hermanos Luis, Lotario y Carlos. A partir de este momento Francia se consideró ofendida y, ya que por las armas y el derecho no consiguió recuperar su hegemonía sobre Europa, lo intentó con los subterfugios y las malas artes. Esto se ha mantenido tras el cambio de dinastía a los Valois y a los Borbones, reinantes en Francia en la figura de Luis XIV en el momento del estallido del conflicto con los Habsburgo. Se tacha a la dinastía Borbón poco menos que de advenediza, ya que apenas lleva doscientos años al frente de la monarquía francesa y carece, por tanto, de cualquier fundamento para recuperar las ambiciones imperiales. Se afirma el carácter electivo del Imperio que, desde hace siglos, ha recaído en la Casa de Austria como por designio divino. De Luis XIV se afirma que es la personificación del mal, ya que ha elegido emplear su fuerza y su poder no para acrecentar la presencia de la fe católica en el mundo, sino para su propia ambición y por ello Francia será recordada como la nación sin fe, sin Dios, sin ley y sin religión.

Se narra cómo, durante los años anteriores a la redacción del escrito, y siendo emperador Leopoldo de Austria, Francia ha mantenido constantes guerras para ampliar sus dominios en Europa. El resto de las potencias, sobornadas o convencidas por Luis XIV, han hecho oídos sordos al expansionismo agresivo francés, siendo el Imperio el único en frenar sus ambiciones. Esto, unido a las antiguas pretensiones imperiales francesas, ha originado que los Habsburgo sean ahora el principal objetivo de Luis XIV en sus dos ramas, la española y la alemana. Mediante el soborno a los ministros de Carlos II, y ante la probabilidad de su fallecimiento sin descendencia directa, el francés minó la imagen alemana entre el pueblo español intentando inclinar su afección hacia Francia. Al mismo tiempo, para debilitar al emperador, fomentó la revuelta de Hungría y el ataque otomano al Imperio que produjo el asedio de Viena en 1683. Se critican del mismo modo, muy ásperamente, la infinidad de guerras causadas en

26. Tromba d'Europa, ipocrisia svelata, Spagna avvisata verità dichiarata, tradotta dal Castigliano in Italiano, Madrid, nella Stamparia di Antonio Bysarron, 1702 (Biblioteca Casanatense). Se trata de la traducción de un libro que, en varias ediciones, vio la luz en España como El clarín de Europa, hipocresía descifrada, España advertida, verdad declarada. Una de las ediciones en Barcelona, por F. Guasch, 1706. 
Europa por Francia durante las últimas décadas que han llevado a las diferentes naciones, aliadas y enemigas, hasta la extenuación, diezmando los recursos económicos y militares de muchos estados.

Se exalta, por el contrario, el carácter benéfico que ha tenido la Casa de Austria con los estados que han estado a su lado, poniendo como ejemplos al duque de Lorena o al de Sajonia, que ha sido encumbrado como rey de Polonia. Se establece, por lo tanto, que los Habsburgo han elegido el camino adecuado y son queridos por Dios, mientras que los Borbones se deslizan por la peligrosa senda del mal que les llevará a la propia destrucción. Dentro de las ambiciones de Luis XIV ha tomado forma la pretensión de anexionar a Francia los territorios de la monarquía hispánica poniendo, para ello, a uno de sus nietos al frente de la corona como un rey títere. Dentro de los movimientos del francés se hace una propuesta de desmembrar los estados que componen España pasando a Francia las posesiones italianas y aceptando dejar al archiduque Carlos la península y América. Este planteamiento, propuesto por Luis XIV antes de la muerte de Carlos II, fue aceptado por Inglaterra, Holanda y Portugal, que ven así mermado el poder español en Europa.

Se exponen, a continuación, los fundamentos genealógicos de las pretensiones francesas y austriacas. El duque de Anjou sería, por un lado, nieto de María Teresa de Austria, primogénita de Felipe IV casada con Luis XIV, además de descender del matrimonio de Luis XIII con Ana de Austria. En favor de Leopoldo se esgrime que en Francia se encuentra vigente la Ley Sálica que no permite la herencia por descendencia femenina. Se establece, además, que la separación de las dos ramas de la Casa de Austria querida por Carlos V establecía que la rama colateral que gobernaba en Austria y el Imperio por mano del hermano de Carlos, Fernando, tuviera derecho de sucesión a la corona española. Se refuerza el papel de Felipe I, marido de Juana la Loca, como rey de Castilla y, por lo tanto, esta y todos sus reinos deberían pasar a los Habsburgo austriacos. El redactor se remite, del mismo modo, a las capitulaciones matrimoniales de los Reyes Católicos según las cuales la Corona de Aragón y todas sus posesiones también pasarían, en caso de extinción de la rama principal, a la Casa de Austria.

Se afirma que ningún testamento puede oponerse al derecho de sucesiones y a las leyes con él vinculadas. El testamento de Carlos II se declara invalidado por ley y por lo establecido en las últimas voluntades de Felipe IV, Felipe III, Felipe II y Carlos V. Además, en las capitulaciones matrimoniales de las princesas españolas de la Casa de Austria con monarcas franceses se estableció la renuncia expresa a cualquier derecho sobre los estados que componen España.

Se proporciona a continuación copia de las principales leyes españolas relativas al derecho de sucesiones como las cláusulas del matrimonio de Ana de Austria con Luis XIII y el extracto de un libro titulado Los derechos de la Casa de Austria, en el que se recogen las cláusulas testamentarias y las 
capitulaciones matrimoniales que sustentan las pretensiones de sucesión dinástica de los Habsburgo.

Por lo que respecta a las potencias europeas, su postura se presenta con tres posibles opciones ante la invasión del duque de Anjou. Los interesados y parientes de la monarquía de España inmediatamente se dispusieron a defender sus derechos. Los príncipes y gobernantes de mayor potencia, excepto Portugal, desconfiados y temerosos de Francia, apoyaron al Imperio de los Habsburgo, aunque, inicialmente, evitando la confrontación directa con Luis XIV. Los estados más débiles intentaron mantenerse neutrales para decantarse por aquel que pareciera ser vencedor de la contienda. La disertación culmina con una llamada a todos los príncipes europeos a darse cuenta del engaño. Se tacha a Francia de ser un estado sin religión, una hidra universal con tantas cabezas como intereses y se insta a toda Europa a liberarse de su yugo.

Inmediatamente después de la Tromba d'Europa se publicaba, con un signo político diametralmente opuesto, La tromba della ribelione spezzata, ${ }^{27}$ que se presentaba, de forma tardía, como respuesta al alegato austriaco que había visto la luz años antes como Lo spartimento del favoloso leone. Sin embargo, la coincidencia de títulos no deja dudas acerca del carácter dialogante de ambos textos. En esta ocasión la propaganda borbónica se ilustraba con un bello grabado en el frontispicio que exalta a Felipe de Borbón, retratado en un óvalo portado por dos ángeles en vuelo, vestido a la española, tal y como se representará en los retratos oficiales de los primeros años de la contienda. ${ }^{28}$ Se muestra la destrucción de esa tromba que yace despedazada en el suelo entre un sol y una corona ante la sorpresa de un guerrero, probablemente Marte, mientras un segundo personaje, desarmado, señala el retrato de Felipe en ascenso a los cielos. En este texto se rebaten, punto por punto, cada uno de los alegatos de Leopoldo I y se descartan las motivaciones del bando austriaco, más emotivas que legales, en un concienzudo examen de las leyes de España.

Los ataques de uno y otro bando por medio del libro impreso continuarán durante años en el medio italiano, decantándose, cada vez más, por la razón legal aquellos que defienden a Felipe de Borbón y por aspectos más subjetivos los que se decantan por el archiduque Carlos. El Papado mantendría una actitud ambigua ante los pretendientes al trono del rey católico aunque pronto, en Roma, junto a los embajadores y los libros, harían su aparición los soldados. ${ }^{29}$

27. La tromba della riblelione spezzata, risposta ad un libro sedizioso intitolato lo Spartimento del Favoloso Leone per difesa de' diritti del Re Cattolico Filippo V sovra la corona di Spagna. Consagrata all'istessa Sagra Real Maestà, Milano, per Marc'Antonio Pandolfo Malatesta, 1703 (Biblioteca Nazionale Centrale Vittorio Emanuele II).

28. Morán Turina, José Miguel, La imagen del rey Felipe V y el arte, Nerea, Madrid, 1990.

29. Véase TAвасchi, Stefano, op. cit., pp. 223-243. También Martín Marcos, David. «Ideología e historiografía en torno al papel del Papado en la Guerra de Sucesión española», Anuario de Historia de la Iglesia, 19, 2010, pp. 361-372. 


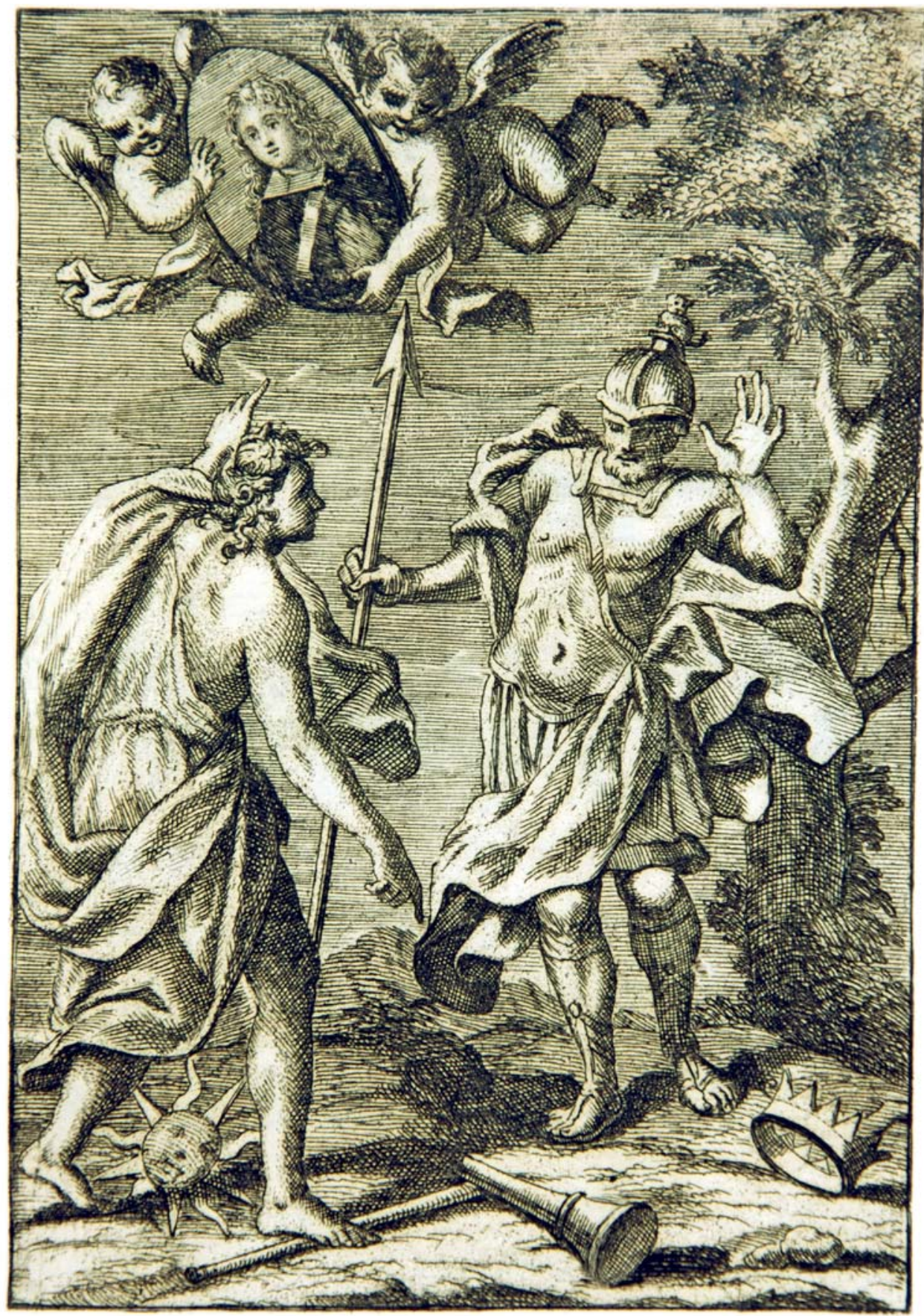

Fig. 9. Frontispicio de La tromba della riblelione spezzata, risposta ad un libro sedizioso intitolato lo Spartimento del Favoloso Leone per difesa de' diritti del Re Cattolico Filippo V sovra la corona di Spagna. Consagrata all'istessa Sagra Real Maestà. Biblioteca Nazionale Centrale Vittorio Emanuele II (Roma) 